\title{
HUBUNGAN ANTARA KEBIASAAN BELAJAR DENGAN HASIL BELAJAR ILMU PENGETAHUAN ALAM (IPA) KELAS VIII DI SMP NEGERI I KEMANG KABUPATEN BOGOR
}

\author{
Rahmad Setyawan dan Sigit Wibowo \\ Pusat Pengembangan SDM Aparatur Perhubungan, Kementerian Perhubungan \\ Jalan Raya Parung-Bogor Km. 26, Pabuaran, Kemang, Kabupaten Bogor. \\ rahmadsetyawan78@gmail.com
}

\begin{abstract}
Abstrak: Penelitian ini bertujuan untuk mengungkap apakah: Terdapat hubungan antara Kebiasaan Belajar terhadap Hasil Belajar IPA. Penelitian ini termasuk jenis penelitian korelasional dengan variabel yang diteliti yaitu: (1) Hasil Belajar IPA (Y); dan (2) Kebiasaan Belajar (X). Sampel penelitian berjumlah 62 peserta didik yang diambil dengan menggunakan teknik sampel acak (random sampling). Pengumpulan data menggunakan instrumen tes dan non-tes. Sebelum instrumen digunakan dalam penelitian, terlebih dahulu diujicobakan pada satu kelas yang setara yang ditetapkan sebagai kelas ujicoba. Kemudian dilakukan uji validitas dan reliabilitas untuk masing-masing instrumen. Uji validitas instrumen tes menggunakan korelasi Point Biserial dan uji reliabilitas menggunakan Kuder Richardson-20 (KR-20), uji validitas instrumen non-tes menggunakan korelasi Product Moment dan uji reliabilitas menggunakan Alpha Cronbach. Hasil penelitian menunjukkan bahwa: Terdapat hubungan positif antara Kebiasaan Belajar dengan Hasil Belajar IPA, nilai korelasi $\left(\mathrm{Ry}_{2}\right)$ 0,435 dapat diinterpretasikan bahwa hubungan kedua variabel penelitian ada di kategori sedang. Berdasarkan hasil penelitian tersebut, Hasil Belajar IPA dapat ditingkatkan dengan cara meningkatkan Kebiasaan Belajar peserta didik.
\end{abstract}

Kata Kunci: $\quad$ Kebiasaan Belajar, Hasil Belajar IPA.

\section{PENDAHULUAN}

Tujuan

pendidikan

mengarahkan para pengajar

mendapatkan mandat atau amanat

untuk mengembangkan kemampuan

yang didapat pada suatu jenjang

pendidikan dalam seluruh aspek

kehidupan, meliputi aspek

pengetahuan (kognitif), aspek

keterampilan (psikomotor), dan aspek sikap (afektif). Di dalam pembelajaran, peserta didik didorong untuk menemukan sendiri dan mentransformasikan informasi kompleks, mengecek informasi baru dengan yang sudah ada dalam ingatannya, dan melakukan pengembangan menjadi informasi atau kemampuan yang sesuai dengan 
lingkungan dan jaman, tempat dan waktu ia hidup

Kurikulum 2013 menganut pandangan dasar bahwa pengetahuan tidak dapat dipindahkan begitu saja dari guru ke peserta didik. Peserta didik adalah subjek yang memiliki kemampuan untuk secara aktif mencari, mengolah, mengkonstruksi, dan menggunakan pengetahuan. Untuk itu pembelajaran harus berkenaan dengan kesempatan yang diberikan kepada peserta didik untuk mengkonstruksi pengetahuan dalam proses kognitifnya. Agar benar-benar memahami dan dapat menerapkan pengetahuan, peserta didik perlu didorong untuk bekerja memecahkan masalah, menemukan segala sesuatu untuk dirinya, dan berupaya keras mewujudkan ide-idenya. Guru memberikan kemudahan untuk proses ini, dengan mengembangkan suasana belajar yang memberi kesempatan peserta didik untuk menemukan, menerapkan ide-ide mereka sendiri, menjadi sadar dan secara sadar menggunakan strategi mereka sendiri untuk belajar. Guru mengembangkan kesempatan belajar kepada peserta didik untuk meniti anak tangga yang membawa peserta didik kepemahaman yang lebih tinggi, yang semula dilakukan dengan bantuan guru tetapi semakin lama semakin mandiri. Bagi peserta didik, pembelajaran harus bergeser dari "diberi tahu" menjadi "aktif mencari tahu".

1lmu Pengetahuan Alam (IPA) mempelajari alam semesta, bendabenda yang ada dipermukaan bumi, di dalam perut bumi dan di luar angkasa, baik yang dapat diamati indera maupun yang tidak dapat diamati dengan indera. Menurut H.W Fowler dalam Trianto (2010: 134), IPA adalah pengetahuan yang sistematis dan dirumuskan yang berhubungan dengan gelaja-gejala kebendaan dan didasarkan terutama atas pengamatan dan dedukasi. Sedangkan Kardi dan Nur dalam Trianto (2010: 134) mengatakan bahwa IPA atau ilmu kealaman adalah ilmu tentang dunia zat, baik makhluk hidup maupun benda mati yang diamati. Adapun menurut Wahana dalam Trianto, IPA adalah suatu kumpulan pengetahuaan yang tersusun secara sistematis dan dalam penggunaannya secara umum terbatas pada gejala-gejala alam.

Menurut Trianto (2010: 134) IPA adalah suatu kumpulan teori yang 
sistematis, penerapannya secara umum terbatas pada gejala-gejala alam, lahir dan berkembang melalui metode ilmiah seperti observasi dan eksperimen serta menuntut sikap ilmiah seperti rasa ingin tahu, terbuka, jujur dan sebagainya. Secara umum IPA terbagi dalam tiga ilmu dasar yaitu biologi, fisika dan kimia. Berdasarkan fungsi dan tujuan tersebut, dapat disimpulkan bahwa hakikat IPA tidak hanya pada dimensi pengetahuan (keilmuan) tetapi juga menekankan pada dimensi nilai ukhrawi. Hal ini berarti memperhatikan keteraturan di alam semesta akan semakin meningkatkan keyakinan akan adanya sebuah kekuatan yang Mahadahsyat yang tidak dapat dibantah lagi yaitu Allah SWT. Dengan dimensi ini, pada hakikatnya IPA mentautkan antara aspek logika-materiil dengan aspek jiwa-spiritual. Proses Pembelajaran IPA berdasarkan Kurikulum 2013 merupakan proses pembelajaran yang integrative atau terpadu. Konsep keterpaduan tampak diperumusan Kompetensi Inti (KI) dan Kompetensi Dasar (KD). Pada Kurikulum sebelumnya atau KTSP, dalam merancang suatu pembelajaran IPA terpadu harus menggabungkan beberapa kompetensi dasar (KD). Pada kurikulim 2013, Penggabungan dalam suatu tema atau topik sudah langsung tersurat dalam Kompetensi Dasar (KD), seperti yang ditulis dalam buku panduan guru IPA (Kementerian Pendidikan Nasional dan Kebudayaan RI, 2013) (Wisudawati dan Sulistyowati 2017: 96).

Berbagai permasalahan dalam implementasi pendidikan IPA yang sesuai dengan hakikatnya sangat kompleks, karena itu pemikiranpemikiran masih terus disumbangkan untuk memecahkan permasalahan itu. Pendidikan IPA dihadapkan dengan permasalahan diantaranya perangkat pembelajaran IPA yang mampu mengintegrasikan berbagai disiplin ilmu melalui tema tertentu, antar konsep dalam satu mata pelajaran dengan konsep mata pelajaran lain, konsep dalam mata pelajaran sehingga guru dan peserta didik memiliki bekal kompetensi dari berbagai disiplin ilmu. Permasalahan mendasar adalah pembelajaran IPA belum berorientasi pada keterampilan proses sains seutuhnya sehingga kemampuan berpikir dan kemampuan 
berinkuiri belum optimal. kali melahirkan pengetahuan Konsekuensi dari produk (knowledge), atau a body of pembelajaran tersebut adalah knowledge. Definisi ini merupakan menurunnya kemampuan berpikir definisi umum dalam pembelajaran kritis dan kreatif, Siswa tidak selalu sains secara konvensional, dan dapat memahami konsep dalam IPA, beranggapan bahwa pengetahuan siswa terkadang menemui kesulitan dalam mempelajari IPA.

Faktor penting keberhasilan siswa dalam pelajaran IPA, selain dari diri siswa sendiri dan motivasi siswa dalam belajar IPA adalah peran serta seorang guru. Seorang guru harus memberikan kesempatan kepada siswa untuk mempelajari IPA sesuai pengetahuannya sendiri. Dalam pelaksanaannya seorang guru perlu menggunakan atau merencanakan model pembelajaran yang tepat untuk dapat menjelaskan materi IPA kepada siswa. Belajar adalah suatu aktivitas atau suatu proses untuk memperoleh pengetahuan, meningkatkan keterampilan, memperbaiki perilaku, sikap dan mengokohkan kepribadian. Dalam proses menjadi tahu atau proses memperoleh pengetahuan, menurut pemahaman sains konvensional, kontak manusia dengan alam diistilahkan dengan pengalaman (experience). Pengalaman yang terjadi berulang sudah terserak dialam, tinggal bagaimana siswa atau pembelajar bereksplorasi, menggali dan menemukan kemudian memungutnya, untuk memperoleh pengetahuan (Hariyanto dan Suyono 2014: 9).

Kebiasaan belajar yang baik memang harus dibentuk dan ditanamkan sejak dini. Sejalan dengan itu, peran orang tua sangat berpengaruh dalam pembentukan kebiasaan belajar yang baik. Umumnya, proses pendidikan mulanya diperkenalkan oleh keluarga. Keluarga merupakan lembaga pendidikan yang pertama dan utama. Sebagai mana mestinya tugas orang tua yaitu memantau kegiatan belajar anaknya di rumah. Orang tua yang acuh tak acuh terhadap kegiatan belajar anaknya, tidak memperhatikan kebutuhankebutuhan anaknya dalam belajar, hal ini sangat berpengaruh terhadap pembentukan kebiasaan belajar 
siswa. Perhatian orang tua tidak pernah lepas dalam mempengaruhi kegiatan belajar anaknya. Adapun fasilitas belajar di rumah mempengaruhi minat dan motivasi anak dalam kegiatan belajar. Fasilitas yang kurang terpenuhi di rumah menyebabkan siswa kurang termotivasi untuk membiasakan diri belajar teratur.

Didapat informasi kebiasaan belajar IPA hasil wawancara bulan September 2017 dengan guru mata pelajaran IPA SMP Negeri 1 Kemang yang mana beberapa siswa kurang baik dalam kebiasaan belajarnya , seperti malas membaca buku dan membuat catatan, tidak fokus memperhatikan penjelasan guru ketika belajar di kelas, tidak mengerjakan tugas dengan baik, dan tidak memiliki jadwal belajar yang pasti di rumah. Selain itu, siswa belum memahami kebiasaankebiasaan belajar yang baik untuk membuat prestasi belajar tinggi. Mengingat paparan di atas, diketahui informasi bahwa kurang baiknya kebiasaan belajar IPA beberapa siswa tampak sejalan dengan rendahnya atau kurang baiknya prestasi belajar
IPA. Faktor yang dapat memengaruhi hasil belajar adalah kebiasaan belajar.

Aunurrahman (2016: 185) mendefinisikan Kebiasaan belajar adalah perilaku belajar seseorang yang telah tertanam dalam waktu yang relatif lama sehingga memberikan ciri dalam aktivitas belajar yang dilakukannya. Hal ini berarti kebiasaan belajar merupakan perilaku belajar yang dilakukan siswa secara berulang-ulang dan lamakelamaan akan menjadi menetap dan bersifat otomatis.

\section{LANDASAN TEORI}

\section{A. Hakikat Hasil Belajar IPA}

Hasil belajar IPA dalam penelitian ini adalah kemampuan yang dimiliki siswa berupa perubahan tingkah laku yang disebabkan adanya pengalaman dan latihan yang diperoleh setelah mengikuti proses pembelajaran IPA pada aspek kognitif, meliputi dimensi pengetahuan (C1) dan pemahaman (C2). Berupa kompetensi dasar: (1) Memahami gerak pada makhluk hidup, sistem gerak pada manusia, dan upaya menjaga kesehatan sistem gerak dengan materi : struktur dan fungsi rangka, sendi, otot manusia, 
struktur gerak, jenis dan perbedaan, menyajikan hasil pengamatan dan identifikasi tentang sistem gerak, mengidentifikasi gangguan pada sistem gerak, upaya mencegah dan cara mengatasinya, gerak dan gaya pesawat sederhana; (2) Pengaruh gaya gerak berdasarkan hukum newton dan penerapanya pada gerak benda dan gerak makhluk hidup dengan materi: Pengertian gerak, jarak dan perpindahan, kecepatan dan kelajuan, gerak lurus, gaya dan hukum newton; (3) Keterkaitan struktur jaringan tumbuhan dan fungsinya, serta teknologi yang terinspirasi oleh struktur tumbuhan dengan materi : struktur dan fungsi tumbuhan, struktur dan fungsi akar, batang dan daun, struktur dan fungsi bunga, buah dan biji, dan teknologi yang terinspirasi oleh struktur tumbuhan.; (4) Mengetahui sistem pencernaan pada manusia dan memahami gangguan yang berhubungan dengan sistem pencernaan, upaya menjaga kesehatan sistem pencernaan dengan materi : bahan makanan dan pengujian kandungan bahan makanan, organ pencernaan, penyakit yang berhubungan dengan sistem pencernaan; (5) Dampak penyalahgunaan zat aditif dan zat adiktif bagi kesehatan dengan materi: Zat adiktif dan jenis zat aditif, pengaruh zat aditif terhadap kesehatan; (6) Mengetahui sistem peredaran darah pada manusia dan memahami gangguan pada sistem peredaran darah, serta upaya menjaga kesehatan sistem peredaran darah dengan materi: Sistem peredaran darah, organ peredaran darah, jenis peredaran darah, penyakit pada sistem peredaran darah, dan cara menjaga kesehatan pada sistem peredaran darah.

\section{B. Hakikat Kebiasaan Belajar}

Kebiasaan belajar adalah cara yang dilakukan seseorang dalam belajar secara terus menerus dan terjadwal,membaca dan membuat catatan, mengulangi bahan pelajaran, konsentrasi dan mengerjakan tugas. 
3. METODOLOGI PENELITIAN

\section{A. Tujuan Penelitian}

Penelitian ini bertujuan untuk menguji/mengungkap apakah terdapat hubungan kebiasaan dengan hasil belajar IPA.

\section{B. Tempat dan Waktu}

\section{Penelitian}

Penelitian dilakukan di SMP Negeri 1 Kemang Desa Tegal Kecamatan Kemang Kabupaten Bogor. Waktu pelaksanaan penelitian dimulai dari November 2017 sampai April 2018.

\section{Metode Penelitian}

Metode penelitian yang digunakan dalam penelitian ini adalah metode survei dengan analisis korelasional, yakni untuk menemukan informasi tentang terdapat tidaknya hubungan antara variabel bebas (prediktor) dan variabel terikat. Sebagai variabel bebas adalah: Kebiasaan Belajar (X), sedangkan variabel terikatnya adalah Hasil Belajar IPA (Y).

Hubungan variabel tersebut dapat digambarkan dalam bentuk konstelasi hubungan sebagaimana dijelaskan pada Gambar 1 berikut:



Gambar 1. Konstelasi Hubungan Antar Variabel Penelitian

\section{Populasi dan Sampling Penelitian}

1) Populasi Penelitian Populasi dalam penelitian ini adalah peserta didik kelas VIII SMP Negeri I Kemang, Desa Tegal, Kecamatan Kemang, Kabupaten Bogor, tahun pelajaran 2017/2018 sejumlah 5 kelas dengan 202 peserta didik seperti yang ditunjukkan pada Tabel 1 berikut.

Tabel 1. Jumlah Populasi Terjangkau

\begin{tabular}{|c|c|}
\hline Kelas & Jumlah \\
\hline VIII 5 & 41 \\
\hline VIII 6 & 40 \\
\hline VIII 7 & 41 \\
\hline VIII 8 & 40 \\
\hline VIII 9 & 40 \\
\hline Jumlah & $\mathbf{2 0 2}$ \\
\hline
\end{tabular}

2) Teknik Pengambilan Sampel Penentuan ukuran sampel diambil menggunakan rumus Slovin:

$$
n=\frac{N}{1+N \cdot e^{2}}
$$

Keterangan: 


$$
\begin{aligned}
\mathrm{n}= & \text { ukuran sampel } \\
\mathrm{N}= & \text { ukuran populasi } \\
\mathrm{e}= & \text { kelonggaran ketidaktelitian } \\
& \text { karenaranan } \quad \text { kesalahan } \\
& \text { pengambilan sampel yang } \\
& \text { ditolerir (pada penelitian ini } \\
& \text { menggunakan 10\%). }
\end{aligned}
$$

Jumlah sampel yang diambil, berdasarkan jumlah populasi dimana 4 kelas ditetapkan sebagai kelas survey dan 1 kelas secara random ditetapkan sebagai kelas ujicoba instrumen yaitu kelas VIII 8 . Pengambilan sampel menggunakan rumus Slovin seperti yang ditunjukkan pada Tabel 2 berikut :

Tabel 2. Jumlah Sampel Penelitian

\begin{tabular}{|c|c|c|}
\hline Kelas & $\begin{array}{c}\text { Jumlah } \\
\text { Siswa }\end{array}$ & $\begin{array}{c}\text { Jumlah } \\
\text { Sampel }\end{array}$ \\
\hline VIII 5 & 41 & 16 \\
\hline VIII 6 & 40 & 15 \\
\hline VIII 7 & 41 & 16 \\
\hline VIII 9 & 40 & 15 \\
\hline Total & $\mathbf{1 6 2}$ & $\mathbf{6 2}$ \\
\hline
\end{tabular}

Selanjutnya teknik pengambilan sampel menggunakan teknik random sampling, dimana 4 kelas tersebut ditetapkan sebagai kelas survey dan 1 kelas ditetapkan sebagai kelas uji coba instrumen.

\section{E. Teknik Pengumpulan Data}

Terdapat dua jenis data yang dikumpulkan dalam penelitian ini, yaitu: (1) data kebiasaan belajar (X), dan (2) data hasil belajar IPA (Y). Teknik pengumpulan data hasil belajar IPA menggunakan hasil ujian yang diperoleh dari guru IPA, sedangkan variabel kecerdasan spasial menggunakan instrumen tes. Penyusunan instrumen berpedoman pada kisi-kisi yang diturunkan dari konsep variabel penelitian.

Untuk kedua variabel tersebut menggunakan instrumen pengumpulan data yang disusun oleh peneliti.

\section{HASIL PENELITIAN}

\section{A. Pengujian Persyaratan Analisis \\ Sebagai persyaratan agar} analisis regresi dapat dilakukan, pengujian persyaratan analisis harus dilakukan. Terdapat tiga persyaratan analisis yang harus dipenuhi, yaitu: (1) syarat normalitas, (2) syarat homogenitas, dan (3) syarat kelinieran $\mathrm{Y}$ atas $\mathrm{X}$ untuk regresi sederhana.

\section{1) Uji Normalitas}

Uji normalitas data dilakukan dengan menggunakan uji Liliefors terhadap nilai galat taksiran regresi $\mathrm{Y}$ atas Xi. Uji normalitas bertujuan untuk membuktikan apakah nilai 
galat taksiran $(\mathrm{Y}-\widehat{\mathrm{Y}})$ berdistribusi normal atau tidak. Hipotesis yang diajukan dalam pengujian ini adalah Ho : $(\mathrm{Y}-\widehat{\mathrm{Y}})$ berdistribusi normal. Kriteria pengujian menggunakan statistik L (Liliefors) sebagai berikut: Ho : diterima jika $\quad \mathrm{L}_{\text {hitung }} \leq \mathrm{L}_{\text {tabel }}$ Ho : ditolak jika $\mathrm{L}_{\text {hitung }}>\mathrm{L}_{\text {tabel }}$

\section{Uji Normalitas $(\mathbf{Y}-\widehat{\mathbf{Y}})$ untuk} regresi $\widehat{\mathbf{Y}}=\mathbf{a}+\mathbf{b X _ { 1 }}$

Uji Liliefors dengan $n=62$ pada taraf signifikansi alpha $=0,05$ didapatkan nilai $\mathrm{L}_{\text {tabel }}=0,113$, dan pada taraf signifikansi alpha $=0,01$ didapatkan nilai $\mathrm{L}_{\text {tabel }}=0,131$.

Hasil uji normalitas $(Y-\widehat{Y})$ untuk regresi $\widehat{\mathrm{Y}}=\mathrm{a}+\mathrm{bX}_{1}$ didapatkan $L_{\text {hitung }}=0,056$. Hasil ini menyimpulkan bahwa $\mathrm{L}_{\text {hitung }}<\mathrm{L}_{\text {tabel }}$ atau $0,056<0,113$ (pada taraf signifikansi alpha $=0,05)$ dan $0,056<$ 0,131 (pada taraf signifikansi alpha $=$ 0,01), maka dapat disimpulkan bahwa sampel berasal dari populasi yang berdistribusi normal.

\section{2) Uji Homogenitas}

Uji homogenitas dimaksudkan untuk memperlihatkan bahwa dua atau lebih kelompok data sampel berasal dari populasi yang memiliki variansi yang sama, dalam hal ini menguji homogenitas varians antara kelompok skor $\mathrm{Y}$ yang dikelompokkan berdasarkan kesamaan $\mathrm{Xi}$. Uji homogenitas dilakukan dengan menggunakan uji Levene Statistic dengan SPSS 20. Dasar pengambilan keputusan dalam uji homogenitas adalah:

a) Jika nilai signifikansi $<0,05$ maka dikatakan bahwa varian dari dua atau lebih kelompok populasi data adalah tidak sama (tidak homogen).

b) Jika nilai signifikansi $>0,05$ maka dikatakan bahwa varian dari dua atau lebih kelompok populasi data adalah sama (homogen).

\section{Pengujian Homogenitas Varians Y} $\operatorname{atas} \mathrm{X}$

Hasil pengujian homogenitas varians Hasil Belajar IPA (Y) atas Kebiasaan Belajar (X) dapat dilihat pada Tabel 3 berikut.

Tabel 3. Hasil Uji Homogenitas Varians $Y$ atas $X$

Test of Homogeneity of Variances

\begin{tabular}{|c|c|c|c|}
\hline $\begin{array}{c}\text { Levene } \\
\text { Statistic }\end{array}$ & Sig. & $\begin{array}{c}\text { Batas } \\
\text { Minimum } \\
\text { Signifikansi }\end{array}$ & Keterangan \\
\hline 1.537 & 0.146 & 0.050 & Homogen \\
\hline
\end{tabular}


Berdasarkan Tabel 3 tersebut, diketahui bahwa nilai signifikansi variabel Hasil Belajar IPA (Y) berdasarkan variabel Kebiasaan Belajar $(X)=0,146$ lebih besar dari 0,050, artinya data variabel Hasil Belajar IPA (Y) berdasarkan variabel Kebiasaan Belajar (X) memiliki varian yang sama (homogen).

\section{Pengujian Hipotesis}

Hubungan antara Kebiasaan Belajar (X) dengan Hasil Belajar IPA (Y)

Hipotesis dalam penelitian ini adalah "terdapat hubungan antara Kebiasaan Belajar dengan Hasil Belajar IPA".

Hasil perhitungan nilai koefisien determinasi menggunakan SPSS dapat dilihat pada Tabel 4 berikut.

Tabel 4. Hasil Perhitungan Nilai Koefisien Determinasi Model Summary ${ }^{b}$

\begin{tabular}{l|c|r|r|r|}
\hline Model & $\mathrm{R}$ & $\begin{array}{c}\mathrm{R} \\
\text { Square }\end{array}$ & $\begin{array}{c}\text { Adjusted } \\
\text { R Square }\end{array}$ & $\begin{array}{c}\text { Std. Error } \\
\text { of the } \\
\text { Estimate }\end{array}$ \\
\hline 1 & $0.435^{\mathrm{a}}$ & 0.189 & 0.176 & 3.253 \\
\hline
\end{tabular}

pedoman untuk memberikan interpretasi koefisien korelasi sebagai berikut:

$0,00-0,199=$ sangat rendah

$0,20-0,399=$ rendah
$0,40-0,599=$ sedang

$0,60-0,799=$ kuat

$0,80-1,000=$ sangat kuat

Berdasarkan hasil tersebut, maka hipotesis yang menyatakan "terdapat hubungan antara Kebiasaan Belajar dengan Hasil Belajar IPA" teruji kebenarannya, yaitu semakin baik Kebiasaan Belajar siswa, maka semakin tinggi pula Hasil Belajar IPAnya.

Nilai korelasi 0,435 dapat diinterpretasikan bahwa hubungan kedua variabel penelitian ada di kategori sedang. Koefisien determinasi (KD) menunjukkan seberapa bagus model regresi yang dibentuk oleh interaksi variabel bebas dan variabel terikat. Nilai $\mathrm{KD}$ diperoleh dari kuadrat koefisien korelasi antara variabel $\mathrm{X}$ dengan $\mathrm{Y}$. Nilai KD yang diperoleh adalah 0,189, yang dapat ditafsirkan bahwa variabel bebas X (Kebiasaan Belajar) memiliki pengaruh kontribusi sebesar $18,9 \%$ terhadap variabel Y (Hasil Belajar IPA) dan $81,1 \%$ lainnya dipengaruhi oleh faktor-faktor lain diluar variabel $\mathrm{X}$. 


\section{SIMPULAN}

Berdasarkan penelitian

korelasional yang telah dilakukan antara Kebiasaan Belajar dengan Hasil Belajar IPA, dapat disimpulkan bahwa terdapat hubungan positif antara Kebiasaan Belajar dengan Hasil Belajar IPA, dimana semakin tinggi Kebiasaan Belajar siswa, maka semakin tinggi pula Hasil Belajar IPA. Dengan demikian, untuk meningkatkan Hasil Belajar IPA dapat dilakukan dengan cara meningkatkan Kebiasaan Belajar siswa.

\section{DAFTAR PUSTAKA}

Aunurrahman. 2016. Belajar dan Pembelajaran, Bandung: Alfabeta.

Hariyanto dan Suyono. 2014. Belajar dan Pembelajaran, Bandung : PT. Remaja Rosadakarya.

Sugiyono, 2010. Metode Penelitian Pendidikan: Pendekatan Kuantitatif, Kualitatif, dan R\&D Bandung: Alfabeta.

Trianto. 2010. Model Pembelajaran Terpadu, Jakarta: PT. Bumi Aksara.

Wisudawati, A. W. dan Sulistyowati, E, 2017. Metodologi
Pembelajaran IPA, Jakarta: PT.

Bumi Aksara, 2017. 